\title{
RSP Revisitada A sociologia de Max Weber
} (Sua importância para a teoria e a prática da Administração)

Texto publicado na RSP de agosto/setembro de 1946 (v. III, ano IX, nos 2 e 3)

A Tradução integral da obra de Max Weber - Wirtschaft und Gesellschaftempreendida pela editora mexicana - Fondo de Cultura Económica, sob a esclarecida direção de José Medina Echavarría, é um acontecimento a cuja magnitude esta Revista não pode permanecer indiferente. É esta a primeira vez que a referida obra aparece em língua diferente da original, pois a anunciada tradução do seu primeiro volume, realizada por Parsons-Henderson, não foi editada até o presente e, ao que me consta, circula mimeografada, em restritos centros de estudo dos Estados Unidos.

Apesar de inacabada e fragmentária e de ser um livro póstumo, publicado graças à dedicação e competência de Marianna Weber, espôsa do autor, Economia e Sociedade é a obra não só onde se reunem os temas centrais de Max Weber, como também onde êle expõe o seu sistema de sociologia.

O responsável por esta seção não tem a veleidade de pretender fazer uma crítica desta obra, cuja influência capital na formação das ciências sociais é hoje 
universalmente reconhecida. Terá atingido o seu objetivo se conseguir, nas linhas que se seguem, expôr com clareza alguns temas fundamentais da sociologia de Max Weber, mais pertinentes ao núcleo de assuntos em que se especializa esta Revista. Para isto, utilizará nêste ensaio, além de Economia e Sociedade, a História Econômica Geral, na tradução castelhana de Manuel Sanchez Sarto (Fondo de Cultura Económica), A Ética Protestante e o Espirito do Capitalismo, na tradução inglêsa de Talcott Parsons, bem como os estudos dêste último em The Review of Politics ( $\mathrm{n}^{\text {os }}$ de janeiro e abril de 1942), sob o título "Max Weber and the Contemporary Political Crisis", e os três estudos de Albert Salomon, "Max Weber's Socliology", "Max Weber's Methodology" e "Max Weber's Political Ideas" (in Social Research, números de maio de 1934, fevereiro de 1935 e agôsto de 1935), e, ainda, outras fontes secundárias ${ }^{1}$.

Não é necessário ser profeta para prever que a obra de Max Weber será para as novas juventudes do mundo atual a propedêutica necessária para o estudo e a compreensão dos problemas sociais, pois ela é a tentativa mais bem sucedida de estabelecimento de uma ciência sociológica da história e, por isto mesmo, de uma sociologia efetiva. $\mathrm{O}$ têrmo efetivo, aqui, aplica-se para ressaltar que a sociologia weberiana é, ela mesma, uma ferramenta, um instrumento que pode ser utilizado na organização da sociedade. A sociologia de Max Weber não é uma construção acadêmica, mas é fruto do esfôrço de um homem, dotado de uma nítida vocação política e também de um acendrado escrúpulo científico, para transpor o abismo em que a sociedade do seu tempo, que é o nosso, parecia afundar-se.

Nela se espelha a consciência do drama de uma época em que os objetivos da sociedade e aquêles da personalidade particular de cada homem parecem contraditórios, época, portanto, èticamente descaracterizada, de onde está banida, por ser desnecessária e inconseqüente, a eloqüência do heroismo humano. Max Weber, tão diferente, nêste particular, de Karl Marx, não é um reformador social, antes, parafraseando Jaspers, uma sociologia, a compreensão militante do seu tempo. Seu nome não servirá, por isto, jamais para bandeira de programas de salvação ${ }^{2}$, pois sua obra é escrupulosamente anti-evangélica e a ilustração mais insofismável de uma elaboração da inteligência consciente dos seus limites e de sua historicidade.

É a partir de Max Weber que a sociologia se emancipa definitivamente do normativismo, se liberta de uma certa tendência reformista que a impelia a invadir, não sem os clamores das vítimas, os feudos da moral, da religião, da profecia e da filosofia.

A importância do estudo da obra de Max Weber decorre principalmente dêste resultado. Se bem feito, o que se ganha com êle é uma atitude genuinamente científica diante do mundo, uma aptidão para discernir o espúrio do legítimo, aptidão tão parcamente distribuída entre os homens e de que tão urgentemente necessita um país culturalmente colonial como o Brasil.

A sociologia weberiana é o melhor antídoto do espírito de proselitismo, da mania escolástica de atribuir rótulos à sociologia, do provincianismo e da suficiência cultural, bem como do hediondo jesuitismo intelectual, cujos produtos ordinários são as inquisições e os processos, a barbárie moral dos incendiários de bibliotecas e dos furibundos fanáticos políticos, degradados e bastardos espirituais de tôda laia. Não que Weber tivesse em mira êste objetivo. Sua obra não se caracterisa pela negação, mas pela 
afirmação. Ela é um sereno encadeamento de enunciações cuidadosamente depuradas de juízos de valor.

\section{Os "tipos ideais"}

Antes de entrarmos na exposição de alguns temas da obra de Max Weber, devemos fazer algumas considerações sôbre o método que êle criou, não só por ser esta uma ordem lógica, como também porque a sua contribuição mais positiva para o desenvolvimento das ciências do mundo histórico consiste no seu método dos "tipos ideais".

As ciências sociais se desenvolveram, inicialmente, sob a tutela das ciências naturais e, até hoje, ainda existem sociólogos adeptos da teoria da evolução emergente para os quais a diferença entre a sociedade e a natureza é apenas quantitativa e não qualitativa. Para êstes, as ciências sociais são ciências naturais e, portanto, a questão da autonomia cujas primeiras é menos uma questão metodológica do que uma questão de fronteiras geográficas, por assim dizer, uma questão de delimitação dos campos específicos das diversas ciências.

Embora se possa remontar a Vico a percepção de que as ciências históricas e as sociais requerem um método próprio de investigação, foi Dilthey quem enfrentou o problema mais decidida e claramente. Segundo Dilthey ${ }^{3}$, há uma incompatibilidade metodológica fundamental entre as ciências da natureza e as ciências do espírito, enquanto o método das primeiras é a explicação e o das segundas é a compreensão. A idéia diltheana da ciência compreensiva foi o início de uma discussão sôbre uma nova teoria científica em que tomam parte Simmel, Windelband e Rickert.
Max Weber tem de comum com êstes filósofos o objetivo, mas, apesar de deverlhes, sobretudo a Rickert, contribuições, encontrou uma solução absolutamente nova do problema. Seu interêsse principal não foi propriamente discutir o dualismo - ciência natural versus ciência cultural -, mas construir para a sociologia um método próprio de investigação.

A categoria central da metodologia de Max Weber é o "tipo ideal", entendendose por esta expressão uma ficção heurística com a qual o cientista ordena uma série de aspectos recorrentes da realidade. Os "tipos ideais" são conceitos puros que necessàriamente representam deformações da realidade.

A noção de "tipo ideal" implica a admissão de que a ciência não é uma cópia da realidade, de que nosso conhecimento da realidade é, portanto necessàriamente limitado e imperfeito. "Tipos ideais" como feudalismo, capitalismo, etc. jamais ocorrem no mundo concreto, com todos os característicos estabelecidos pelo cientista. São exageros propositados de situações concretas, cuja finalidade é servir para estimar o grau de pureza ou hibridês dos fatos.

O "tipo ideal" é um conceito tecnicamente elaborado. Não é um achado, nem uma descoberta, mas uma projeção vigorosa do espírito do cientista sobre a realidade, uma violentação desta.

Para construir o "tipo ideal" de uma conduta ou de uma instituição, por exemplo, não podemos simplesmente retratá-las ou copiá-las, mas devemos imputar-lhes um fim e anotar sòmente os aspectos que tomam sentido com referência a êste fim, o que significa dizer que devemos estropriar a expressão concreta da conduta ou instituição. Os tipos ideais - diz Weber - expõem como se 
desenvolveria uma forma especial de conduta humana, se o fizesse com todo o rigor com respeito ao fim, sem perturbação alguma de erros e efeitos e de sua orientação unívoca para um só fim ${ }^{4}$.

Além desta compreensão típico-ideal, Max Weber se refere a uma compreensão de caráter endopático, baseada na capacidade afetiva ou receptivo-artístico do sujeito. Muitos sentimentos reais - diz Weber - (medo, cólera, ambição, inveja, ciúme, amor, entusiasmo, orgulho, vingança, piedade, devoção e apetites de tôda sorte) e as reações irracionais (do ponto de vista da ação racional com referência aos fins) dêles derivados podem ser "revividos" afetivamente de modo tanto mais evidente quanto mais susceptíveis sejamos dêstes mesmos sentimentos; e, em todo caso, ainda que excedam em absoluto; por sua intensidade a nossas possibilidades, podemos compreendê-los endopàticamente em seu sentido, e calcular seus efeitos sôbre a direção e os meios de ação ${ }^{5}$.

Não presume esta teoria do conhecimento que o mundo histórico esteja escrito em linguagem típico-ideal.

Ao contrário, está consciente de que os "tipos ideais" são meras convenções, mero código, meras hipóteses de trabalho com que opera o cientista. As implicações desta teoria são profundas. Uma delas é um ceticismo absoluto, uma descrença na possibilidade de o homem perceber o sentido imanente da história. Max Weber não nega nem afirma que a história tenha um sentido. Segundo êle, nós podemos interpretar o acontecer mediante tipos ideais, mas não podemos garantir que nenhuma interpretação de sentido seja a interpretação causal válida ${ }^{6}$. A ordem típico-idealmente construída é uma ordem arbitrária e imposta ao mundo histórico. Nisto se patenteia o escrúpuloantievangélico, anti-dogmático, anti-teológico, minuciosamente científico de Max Weber. Sua obra, neste particular; não pode ser confundida com a de Hegel e Spengler ou Arnold Toynbee $^{7}$ e a dos epígonos plebeus do marxismo $^{8}$ que acreditam não só num desenvolvimento imanente ${ }^{9}$ da história, como na possibilidade de conhecer a verdadeira direção dêste desenvolvimento.

Esta concepção de ciência é eminentemente anti-socrática. O conceito socrático de ciência supunha uma relação conatural entre o indivíduo e o universo. A ciência, segundo Sócrates, está infusa no homem e êste a adquire desenvolvendo-a dentro de si como um embrião se desenvolve no seio materno. A concepção típico-ideal da ciência é o reverso do socratismo. O espírito humano e o mundo são inconversíveis. O homem está ilhado e nenhuma garantia possui de que a sua ciência seja uma expressão verdadeira do que o mundo é em si mesmo. Assim sendo, importa menos conhecer a forma ou substância do universo do que conhecer como podemos dominá-lo ou conjurar a sua irracionalidade.

A concepção típico-ideal da ciência exprime o desespero da consciência humana diante do fracasso da explicação religiosa ou mágica das forças do mundo histórico. Ela é representativa de uma época secularizada em que os padrões sagrados foram radicalmente minados pelo trabalho corrosivo da razão.

\section{Conceito funcional de racio- nalidade}

Uma das contribuições mais fecundas de Max Weber é a distinção entre a racionalidade e a irracionalidade, em têrmos de função antes que de substância. Se bem 
que ela não esteja explícita, há em sua obra numerosos trechos em que está subentendida.

No parágrafo inicial de Economia e Sociedade, diz Max Weber: "Por 'ação' deve entender-se uma conduta humana (quer consista em um fazer externo ou interno, quer em um omitir ou permitir) sempre que o sujeito ou os sujeitos da ação atribuam-lhe um sentido subjetivo. A 'ação social', portanto, é uma ação onde o sentido intencionado por seu sujeito ou sujeitos está referido à conduta de outros, orientando-se por esta em seu desenvolvimento" ${ }^{\prime 10}$.

E, mais adiante, explicando o que entende por "sentido" afirma que não se trata de um sentido "verdadeiro", metafisicamente fundado ou de um sentido "objetivamente justo", motivo por que se põe em evidência o caráter não-dogmático ou valorativo da sociologia em face das ciências dogmáticas, como a jurisprudência, a lógica, a ética e a estética", as quais pretendem investigar nos seus objetos o sentido "justo" e "válido". Para estas ciências, os têrmos racional e irracional são considerados sob o paradigma da essência e da substância.

Sociològicamente tôda conduta ou ocorrência que se integra numa conexão de sentido é racional com referência a êste sentido. $\mathrm{Na}$ série de atos preparativos de um indivíduo que deseja suicidar-se, cada ato é racional com referência ao objetivo por êle intencionado e será irracional qualquer ato (a conduta de um amigo ou de um médico) visando impedir que êle atinja o seu objetivo. Nêste caso, uma racionalidade se contrapõe a outra.

Em seu ensaio, A Ética Protestante e o Espirito do Capitalismo, Max Weber ilustra o conflito de racionalidades nas seguintes palavras: "Há, por exemplo, a racionalização da contemplação mística, isto é, de uma atitude que, vista de outros departamentos da vida, é especificamente irracional, como há também racionalizações da vida econômica, da técnica, da pesquisa científica, do treinamento militar, da lei e da administração. Além disto, cada um dêstes campos pode ser racionalizado em têrmos de valores ou fins inteiramente diversos, e o que é racional de um ponto de vista pode ser irracional de outro. Racionalizações do mais variado caráter têm existido em vários departamentos da vida e em tôdas as áreas de cultura. Para caracterisar as diferenças entre elas do ponto de vista da história cultural, é necessário saber que departamentos são racionalizados e em que direção" ${ }^{11}$. Nesta acepção, a racionalidade ou a irracionalidade perdem o caráter intrínseco e adquirem sentido somente quando se objetiva um valor ou fim. Mannheim utilizou, com habilidade, esta acepção funcional e faz dela uma viga mestra de sua teoria da organização social. Com muita propriedade acentuou que um ato racional não é necessàriamente um ato inteligente, mas o é, se a sua ocorrência se ajusta à função de um sistema de outros atos.

\section{A ratio}

É necessário não confundir o conceito funcional de racionalidade e irracionalidade com aquilo que se poderá chamar de processo de racionalização. É verdade que muitos trechos de Max Weber estão redigidos de modo a pe:rmitir esta confusão. Mas uma leitura atenta dos mesmos verificará tratar-se simplesmente de homonímia. Tôda a obra de Max Weber pode ser considerada como um estudo do processo de racionalização da esfera da religião, da moral, do direito, da $\operatorname{arte}^{12}$, da economia, da política, etc. 
Nêste particular, é que ela muito se assemelha ao estudo de Durkheim, em De la Division du Travail Social, ao de Tönnies, em Gemeinschaft und Gesellschaft, ao de W. G. Sumner, em Folkways e, por fim, ao de Arnold Toynbee, em A Study of History.

A ratio é, na história, um instrumento que tem servido para emancipar o indivíduo da tradição e para erradicar o medo do sagrado. Ela é, por excelência, o instrumento de secularização. A verdadeira dialética é a do racionalismo contra o tradicionalismo, a do movimento contra a inércia.

Se se entende bem o princípio weberiano de racionalização, ter-se-á captado, sem nenhuma sombra de dúvida, a significação verdadeira desta sociologia. O seguinte trecho é, ao nosso ver, básico para um perfeito entendimento daquilo que o nosso autor chama de racionalização:

"Chamamos comunidade - diz Weber - a uma relação social quando e na medida em que a atitude na ação social - no caso particular, por têrmo médio ou no tipo puro - se inspira no sentimento subjetivo (afetivo ou tradicional) dos participantes de constituir um todo.

Chamamos sociedade a uma relação social quando e na medida em que a atitude na ação social se inspira em uma compensação de interêsses por motivos racionais (de fins ou valores) ou também em uma união de interêsses com igual motivação ${ }^{13}$."

A racionalização é a transformação da comunidade em sociedade, isto é, da organização social fundada na santidade da tradição e nos sentimentos humanos em uma organização social fundada na calculabilidade dos atos e na objetividade racional.

\section{Os tipos ideais de dominação}

A breve dissertação metodológica precedente pode ser ilustrada com uma exposição dos tipos ideais de dominação. Max Weber entende por dominação tôda probabilidade de um mandato encontrar obediência entre determinadas pessoas e distingue, no mundo histórico, três tipos de dominação: a dominação racional-legal, a dominação tradicional e a dominação carismática. Em mais de um trecho de Economia e Sociedade, assinala que os vários tipos de dominação não se sucedem unilinearmente, evitando, assim, sejam considerados como fases subseqüentes de uma evolução necessária.

\section{a) A denominação racional-legal}

Cada tipo de dominação é caracterizado pela espécie de legitimidade que a fundamenta. A dominação racional-legal se baseia na legalidade definida por normas e estatutos jurídicos objetivos e seus caraterísticos principais são:

a) o soberano não exerce o mandato segundo o seu arbítrio, mas está subordinado a leis conforme as quais pauta os seus atos;

b) a obediência ao soberano não é entendida como uma obediência a sua pessoa, mas a um ordem impessoal;

c) existe uma separação entre o patrimônio público e o patrimônio privado. Os funcionários não se apropriam dos cargos e estão sujeitos à prestação de contas;

d) rege o princípio da competência e da hierarquia administrativas. A cada autoridade é atribuído um conjunto de funções, 
como também um certo grau da escala administrativa;

f) os "casos" são resolvidos mediante a aplicação de regras técnicas e de normas;

g) exige-se dos funcionários um saber profissional e o recrutamento dos mesmos é realizado de modo competitivo, tendose em vista o mérito e a capacidade dos candidatos.

A concretização mais pura dêste tipo de dominação é a chamada administração burocrática em que desaparece totalmente a relação servil entre o soberano e o funcionário que, neste caso, é pessoalmente livre.

A administração burocrática é uma peça da sociedade de massas. Numa sociedade cujo princípio é a nivelação democrática dos grupos e dos indivíduos, a administração burocrática é um imperativo inelutável. Num complexo cultural em que se realiza o conceito de cidadão, em que o Estado não se defronta com estamentos, ciosos de sua "honra estamental", a existência de uma administração burocrática é a garantia de sua subsistência histórica. Quanto maior a eficácia do processo de democratização, mais numerosos os domínios da vida em que a burocracia intervém. Esta tendência, atuamente inelutável, Max Weber faz questão, em tôda sua obra, de acentuar, não sem uma certa melancolia, pois êle enxergava os seus efeitos negativos sôbre a personalidade. Com o desenvolvimento da burocracia, torna-se cada vez mais estreita a esfera onde se realiza a "existência qualitativa", onde se realiza a singularidade específica do ser humano. Contudo, Max Weber, ao tratar da burocratização, não a estigmatiza à maneira de Ruskin, de Rilke de George Sand, de Tolstoi, se bem que entremostre o seu horror por uma humanidade profissionalizada, por um mundo em que não haverá mais a aventura, mundo em que cada vida deverá transcorrer dentro de uma "carreira"14.

\section{b) A dominação tradicional}

A dominação tradicional se fundamenta na santidade da tradição e na crença na legitimidade do soberano, assinalado pela tradição, para exercer o mandato. Aqui não se conhece a regra ou norma objetiva e racional, nem pode haver uma criação deliberada de estatutos jurídicos e administrativos. Os dominados devem obediência à pessoa do soberano, do qual são "servidores", o conceito de "funcionário" sendo mais próprio para os profissionais $\mathrm{da}$ burocracia. Originàriamente, a dominação tradicional não possui quadro administrativo e os dominados são "companheiros tradicionais" do senhor, seus "iguais" e não seus "súditos". Êstes tipos originários de dominação tradicional são a gerontocracia (autoridade exercida pelos maiores em anos) e o patriarcalismo.

Com o aparecimento do quadro administrativo, a dominação tradicional se transforma em patrimonialismo ou no tipo marginal entre o tradicionalismo e o carismatismo - o sultanato.

A espécie de patrimonialismo mais conhecida na história é a dominação estamental ${ }^{15}$ em que "determinados poderes de mando e suas correspondentes probabilidades econômicas estão apropriados pelo quadro administrativo". Na dominação patrimonial, os dominados são "súditos" do soberano e por êste ordinàriamente lhes é garantida a manutenção, quando não tornando-os seus comensais, por meio de "prebendas" (doações de dinheiro e bens, de "terras de serviço" (Dienstland), apropriações de rendas, direitos ou tributos) ou de feudos. 
O quadro administrativo neste caso, pode ser recrutado:

\section{a) patrimonialmente:}

1) entre os da mesma linhagem;

2) entre os escravos;

3) entre os domésticos;

4) entre os clientes;

5) entre os colonos;

6) entre os libertos.

b) extra-patrimonialmente:

1) por relações pessoais de confiança ("favoritos");

2) por pacto de fidelidade com o senhor legitimado (vassalo);

3) funcionários que entram livremente na relação de piedade.

A estrutura patrimonial é pre-burocrática e, por isto, incompatível com a economia, o direito e a política fiscal racionais.

\section{c) A Dominação Carismática}

A palavra "carisma" é sinônimo de graça. O carisma é uma qualidade extraordinária, extracotidiana, sobrenatural que se reconhece numa personalidade a cujo poder se adere inquestionàvelmente, em razão mesma de sua virtude. A dominação carismática é, portanto, livre de qualquer subordinação, seja à tradição, seja a normas racionais. O carisma é uma fôrça antitradicional e anti-racional.

Na dominação carismática, não há nenhuma noção de jurisdição hierárquica ou de competência. Em lugar de um quadro administrativo, existem os "discípulos", o "séquito", "os homens de confiança". O soberano carismático é um "caudilho", um profeta, um anunciador e criador de novos mandamentos. Sua terminologia típica é: "estava escrito, mas em verdade vos digo". Sôbre êste "poder revolucionário especificamente 'criador' da história" assim se exprime Max Weber: "O carisma é a grande fôrça revolucionária nas épocas vinculadas à tradição. À diferença da fôrça igualmente revolucionária da ratio que, ou opera exteriormente pela transformação dos problemas e circunstâncias da vida - e, portanto, de modo mediato, mudando a atitude diante dêles - ou por intelectualização, o carisma pode ser uma renovação interior que, nascida da indigência ou do entusiasmo, significa uma variação de direção da consciência e da ação, com reorientação completa de tôdas as atitudes em face das formas de vida anteriores, ou em face do mundo em geral. Nas épocas pre-racionalistas, tradição e carisma dividem entre si a totalidade das direções de orientação da conduta".

Contudo, a dominação carismática é intrìnsecamente precária e transitiva. $\mathrm{O}$ seu caráter extraordinário a impede de durar. Quase só existe, brevemente, in statu nascendi, tendendo sempre a transformar-se, a rotinizar-se, assumindo formas tradicionais ou burocráticas.

\section{$\mathrm{O}$ rendimento sistemático do} método tipológico

Não será demais repetir que o que se espera conseguir com a criação de tipos ideais, como os que acabamos de expor é, apenas, "um rendimento sistemático". Nunca se poderá encontrar na realidade uma forma histórica que seja uma ilustração pura de um tipo ideal. De fato, na vida social o que existem são formas híbridas, com uma aproximação maior ou menor de determinado conceito puro. Mas disto não se conclui que os tipos ideais sejam elaborações ociosas, de nenhuma importância prática. Ao contrário, na base da crítica típico-ideal das instituições é que 
podemos intervir na organização da sociedade, enquanto esta organização significa desembaraçar a sociedade dos obstáculos que a impedem de atingir a plenitude de sua forma. O que é a teoria do "cultural lag" senão a percepção de que a persistência de certos padrões é inadequada a determinada etapa social? Em face da análise típico ideal da sociedade, teorias como esta revelam o seu caráter elementar. A teoria do "cultural lag" nada mais é do que uma verificação episódica da hibridès das formas sociais.

Recentemente Emílio Willems ${ }^{16}$, uma das figuras mais representativas da sociologia no Brasil, ao lado de Fernando de Azevedo, Gilberto Freyre, Oliveira Vianna, Carneiro Leão, fez um lúcido tratamento da administração brasileira, à luz do método tipológico. Neste trabalho, ficou patente o que muitos percebem de maneira intuitiva, ficou patente que a administração brasileira está atingida de pronunciada hibridês. Nela, ainda persistem muitos resíduos de patrimonialismo, tais como o regime de pistolões, a sinecura, o personalismo político, tudo isto contraposto à índole do atual estágio da civilização ocidental.

\section{Sociologia do partido político}

De grande rendimento sistemático é também o estudo que faz Max Weber dos partidos políticos. Segundo êle, êstes podem ser distinguidos, quanto à finalidade, em partidos de patronagem, quando o seu objetivo é colocar no poder determinado chefe; em partidos estamentais ou classistas, quando são representativos de determinadas camadas da sociedade e ideológicos, quando se interessam pela reconstrução da sociedade, conforme os ditames de uma nova concepção do mundo.
Emílio Willems, no seu citado estudo, teve oportunidade de esboçar um tratamento típico-ideal de nossa política e se referiu à existência de traços do primeiro tipo no Brasil. É conhecido entre nós o regime dos "correligionários" de A ou B que se acreditam fiéis ao seu chefe e não aos seus cargos. Os dois partidos tradicionais dos Estados Unidos participam acentuadamente daquela primeira espécie. Os partidos classistas ou estamentais se concretizam de modo quase puro na Inglaterra, onde até mesmo o partido trabalhista não constitui exceção. O partido comunista no Brasil, como em tôda a parte, é um exemplo de partido ideológico. O nazismo é uma combinação ideológico-carismática.

Ainda que esta classificação de Max Weber não implique nenhuma estimação valorativa, pode, entretanto, servir de fundamento para uma crítica sociológica de um dado momento da vida política. Assim, creio não incorrer em êrros se afirmar que os partidos de patronagem e os classistas ou estamentais são inadequados aos regimes democráticos, sua existência constituindo, muitas vêzes, sérios empecilhos, sobretudo à realização da democracia econômica. Atualmente, os partidos são obrigados a agir na base de programas sociais que objetive menos o sucesso pessoal de um líder ou a ascensão de um grupo do que o bem-estar coletivo. Ainda que os programas sejam disfarces de interêsses personalistas, estamentais ou classistas, um partido político limita extraordinàriarnente as probabilidades de adesões espontâneas das massas, apresentando-se-!hes sem uma ideologia.

Um estudo interessante que está ainda por ser feito é o da teoria e prática do partido $^{17}$. De fato, em tôda organização partidária, há uma ficção e uma realidade. A verdadeira fisionomia do partido 
aparece não quando se consideram apenas as suas plataformas, mas o seu financiamento, a psicologia de seus dirigentes e de seus membros ativos, a sua técnica de manipulação da opinião pública, bem como, subsidiàriamente, sua história.

\section{A ética do valor absoluto e ética da responsabiliade}

Com referência, ainda, à política, Max Weber estabeleceu duas categorias de conduta: uma orientada pela ética do valor absoluto (Gesinnugsethik) e outra orientada pela ética da responsabilidade (Verantwortungsethik) $^{18}$. Numa época em que vários estilos de comportamento coexistem, todos êles tendo garantida sua vigência pela lei secular, a conduta, de grupos e indivíduos, subordinada à ética do valor absoluto, assume necessàriamente um caráter heróico e leva os que a incarnam ao martírio e à auto-destruição. A ética do valor absoluto é incompatível com o caráter secular ${ }^{19} \mathrm{da}$ sociedade atual que carece, justamente, de um ethos unanimemente proclamado. Daí o caráter cismático desta espécie de moral política e sua tendência à inquisição, quando, alguma vez, ocorrências põem o govêrno nas mãos dos seus aderentes. Por ser absolutista, esta conduta está inspirada pelo intento de "salvar" o mundo, edificandoo segundo os moldes que são estimados os certos e naturais. Os adeptos da ética do valor absoluto são personalidades às quais, ordinàriamente, falta a capacidade de orientar as suas ações de modo funcional, personalidades constitucionalmente predispostas à neurose e à psicose $\mathrm{e}^{20}$, porque lhes falece a visão estrutural de sua época. $\mathrm{Na}$ esfera política, a ética do valor absoluto costuma ser o sustentáculo da ditadura e da tirania.
Quanto à ética da responsabilidade, trata-se de uma estratégia intelectual. Aqui a preocupação se dirige menos para a substância da ação do que para o seu fim. Daí a racionalidade desta conduta, não obstante, impregnada de uma gravidade moral que a exime da impugnação de maquiavelismo. O sujeito èticamente responsável considera as conseqüências de suas ações e submete todo impulso irracional ao principio da economia estrutural das instituições. Infensa ao utopismo, ao milenarismo e às manifestações quiliásticas, a ética da responsabilidade objetiva desembaraçar o sistema social de todo obstáculo que, manietando suas forças legítimas, ameace o seu equilíbrio.

\section{A teoria do capitalismo}

Capítulo que não se poderá negligenciar na obra de Max Weber é o seu estudo do capitalismo. Nêle se evidencia a penetração e a fecundidade do seu método, alerta a todos os fatôres atuantes na configuração de um fenômeno. Explicando a origem do capitalismo, Max Weber rejeita inicialmente a teoria daqueles que o derivam do instinto aquisitivo ou que o fazem simplesmente uma decorrência das transformações dos modos de produção e circulação. Quanto à primeira hipótese, observa que o instinto aquisitivo se encontra em tôdas as épocas e, não obstante, o capitalismo é uma forma típica do mundo ocidental moderno. Sem negar que o instinto aquisitivo tenha desempenhado um papel no desenvolvimento do capitalismo, mostra que não pode ser considerado como causa do mesmo.

Quanto à segunda hipótese, imputalhe uma certa miopia sociológica, pois considera uma etapa já avançada do capitalismo como representativa dêste, 
desdenhando as suas origens. Efetivamente, a explicação materialista do capitalismo só é convenções veneráveis, do esquema de ética social consagrado, e da lei tanto da Igreja como da maioria dos Estados europeus $^{21}$. E acentuando o ímpeto heróico da burguesia nascente, acrescenta ainda Tawnay: "Uma inovação tão questionável demandava dos pioneiros que a experimentavam, em primeiro lugar, tanta originalidade, confiança em si mesmos e tenacidade em seus propósitos quanta se requer hoje daqueles que tiverem de transpor a teia que êla teceu. Que influência os impelia a desafiar a tradição? De que fonte êles derivavam os princípios para substituí-la?"22

A resposta de Max Weber à última pergunta é que é a ética puritana que constitui aquela fonte. Segundo êle, o espírito do capitalismo precedeu o regime capitalista. Atualmente estamos imersos num sistema social capitalista. Fomos manipulados, desde que nascemos, pelas exigências desta ordem. Nenhuma dificuldade tem o empresário capitalista de recrutar trabalhadores adestrados nos misteres de que carece. A estrutura atual de nossa sociedade parece natural a uma reflexão ingênua e só à fôrça de uma superação sociológica, poderemos remontar às origens da economia capitalista e assim perceber o seu carater problemático, in statu nascendi.

A economia medieval era uma economia orientada no sentido da satisfação das necessidades e, por sua vez, o trabalhador medieval típico, ajustado à divisão estamental da sociedade, visava, com o seu trabalho, satisfazer as suas necessidades pessoais. Faltava-lhe o ânimo do lucro, a auri sacra fames, o espírito de tesaurisação, o espírito de emprêsa, a atitude racionalizadora, em resumo, o espírito do capitalismo que, segundo Weber, é uma emanação da ética protestante ou, mais pròpriamente, puritana. No capítulo II do seu ensaio - A Ética Protestante e o Espirito do Capitalismo - faz uma longa análise dos textos de Benjam:n Franklin, extraído de suas obras Advice to a Young Tradesman e Necessary Hints to Those that Would be Rich, para mostrar como o ethos puritano tomou forma em radical oposição ao ethos medieval. Foi a ética puritana que, segundo Weber, forneceu ao europeu da fase pré-capitalista as racionalizações justificadoras de uma conduta anti-tradicionalista. O conceito, que pôs em voga, de "vocação" transformou gradualmente, de Lutero a Calvino, o trabalho numa tarefa ascética $^{23}$, Max Weber dá ao conceito calvinista de vocação uma extraordinária importância no desenvolvimento do capitalismo. Acentua que Calvino considerava a vocação como um empreendimento que o indivíduo deveria levar a efeito "com um senso de responsabilidade religiosa" (Tawnay), pondo nela o máximo de zêlo possível. A "vocação", neste caso, não é uma condição definitiva imposta por Deus ao homem à qual este deve conformar-se. É uma atividade escolhida pelo próprio homem que deve ser bem executada. Não o ócio e o divertimento - interpreta Max Weber - mas a atividade serve para aumentar a glória de Deus, de acôrdo com as definidas manifestações de Sua vontade. O calvinismo introduziu, portanto, no sistema medieval, com êste tipo de conduta, um fermento anti-tradicionalista. $\mathrm{O}$ verdadeiro inimigo do catolicismo foi o calvinismo, pois, enquanto o primeiro sancionava uma teoria providencialista com respeito ao esquema medieval da sociedade e estigmatizava como cupidês o espírito de tesaurisação, o segundo espiritualizou o instinto aquisitivo e implìcitamente adotou uma teoria de que o trabalho social é 
dividido entre os homens, não segundo as suas categorias, mas segundo os seus méritos. As estatísticas, comprovam que, em regra, os países católicos eram econômicamente mais atrasados do que os países protestantes - o que indica as conseqüências práticas desta moral.

É uma lamentável deformação inferir desta teoria que Max Weber afirmava ser o protestantismo a causa do capitalismo. Êle próprio, repetidas vêzes, esclarece que não é êste o sentido dos textos de sua sociologia da religião. O que pretende é avaliar a participação da conduta religiosa no desenvolvimento do capitalismo, admitindo, ao mesmo tempo, que inúmeras circunstâncias históricas que não se reduzem necessàriamente à lei econômica, deveriam ter concorrido para a formação das novas igrejas. O que se poderá dizer, com segurança, a respeito da teoria do capitalismo de Max Weber e, aliás, de sua teoria sociológica geral, é que ela repugna o princípio de causa e efeito, que substitui pelo princípio de interdependência estrutural. Trata-se de uma teoria que não pode ser reduzida a fórmula, que não é nenhum leito de Procusto da realidade histórica e que apenas dá frutos quando instrumentalizada por um pesquisador dotado de astúcia, finura, vivacidade e plasticidade.

Não quero deixar passar a oportunidade de mencionar dois livros que julgo fundamentais para quem deseje assimilar o approach weberiano: A Sociologia da Renascença, de Alfred von Martin, onde se faz uma análise contrapontística extraordinàriamente viva $\mathrm{da}$ emergência $\mathrm{da}$ burguesia e, sôbre o mesmo assunto, $A$ Formação da Consciência Burguesa de Bernahrd Groethuysen, êste último, entretanto, mais fiel a Dilthey.

Muito menos se poderia afirmar que Max Weber é autor de uma teoria espiritualista do capitalismo, uma espécie de Anti-Marx, como parece insinuar Albert Salomon. Na verdade, Marx (a quem se atribui a frase: "Moi, je ne suis pas marxiste") também associou ao desenvolvimento do capitalismo a presença de móveis religiosos e até do puritanismo ${ }^{24}$. De resto, entre Karl Marx e Max Weber, apesar de radicais diferenças, há menos contrastes do que tácitos acôrdos...

\section{Conclusão}

Ousando nesta Revista uma exposição da sociologia de Max Weber, pretendo trazer a debate um modo de ver cuja possibilidade de aplicação ao estudo da administração já foi posta a prova, com êxito. No Brasil, Emílio Willems aplicou-o, como referimos acima, na avaliação sociológica de nossa organização política e administrativa. Um dos estudos clássicos da administração Suíça é o trabalho (no qual a influência de Max Weber é indisfarçável) de C. J. Friedrich e Taylor Cole, Responsible Bureaucracy, utilizado, ainda, por Marshall E. Dimock e Howard K. Hyde, na monografia Bureaucracy and Trusteeship in Large Corporations, escrita para o Temporary National Economic Committee.

Estudos desta natureza se coadunam perfeitamente com a alta concepção de técnica de administração ${ }^{25}$, que faz êste Departamento Administrativo do Serviço Público, aliás já formulada claramente em duas exposições de motivos ao Presidente da República. Uma delas, apoiada em Wilmerding, atribui aos técnicos de administração a finalidade de assessoriar as autoridades do govêrno, na formulação da política. A mais recente insiste em que "para colaborar nos estudos que envolvem a política administrativa é necessário possuir um alto nível cultural e experiência muito 
acima da que se deve exigir para o trato das questões de administração de pessoal, material, etc., que constituem o que convencionalmente se chama a administração geral (D.O. 17-3-44)".

Não hesito em afirmar que a sociologia de Max Weber vem atender, em parte, a êste desígnio, pois ela é um instrumento não só necessário, mas indispensável para que a técnica de administração adquira a consciência de suas relações estruturais com os demais departamentos do todo político-social e, dêste modo, possa intervir no processo social, não com expedientes perturbadores, mas colaboradores e até estimuladores daquelas fôrças de cuja libertação depende a realização mesma das potencialidades representativas de uma época.

\section{Notas}

${ }^{1}$ Principalmente, Sorokin, "Les Theories Sociologiques Contemporaines"; E. S. Bogardus, "The Development of Social Thought"; José Medina Echavarría, "Panorama de la Sociologia Contemporánea"; Hans Freyer, "Sociologia, ciencia de la realidad”; Barnes e Becker, "História del Pensamiento Social"; Wiese-Becker, "Systematic Sociology"; José Medina Echavarría, "Sociologia, Teoria y Técnica”; Gurvitch-Moore, "20th. Century Sociology”; Hans Speier, "Max Weber”, verbete, in "Encyclopaedia of the Social Sciences"; Reinhard Bendix, "Marx Weber's Interpretation of Conduct and History", in the American Journal of Sociology", maio de 1946, e Francisco Ayala, notas de aula.

${ }^{2}$ Confrontando Karl Marx com Weber, diz Albert Salomon: "Marx represents the first great example of the interaction of revolucionary fanaticism with the striving for scientific knowledge. All previous revolucionary ideologists had oriented themselves around the eternal ideas of justice and divine order. Even in a secularized form they still clung to the concepts of Christian natural law. Marx, for the first time, made the attempt to determine revolucionary developments from the scientific knowledge and thus make them take on the character of necessity. This very combination of scientific spirit with political and revolucionary pathos was extremely fruitful in its very positing of the question, but at the same time it also set up certain limitaions to knowledge. In a dogmatic historical and social theory reality can apper only in a distorted form" ("Social Research", agôsto, 1935).

${ }^{3}$ Cf. Alexander Goldenweiser, The Relation of the Natural Sciences to the Social Sciences, in Contemporary Social Theory, por H. E. Barnes, H. Becker e F. B. Becker, 1940 - New York-London.

${ }^{4}$ Cf. Economia y sociedad (Fondo de Cultura Económica) pp. 8-9. Mais adiante diz Weber: "Só em casos raros, e isso de maneira aproximada, a ação real transcorre como foi construída no tipo ideal" (p. 9).

${ }^{5}$ Op. cit. pp. 5 e 6.

${ }^{6}$ Op. cit. p. 9.

${ }^{7}$ Cf. Howard Becker e Philip Fröhlich, "Toynbee y la Sociologia Sistematica", "Jornadas" no 32, edição de El Colegio de México. Trata-se de uma crítica positiva de A Study of History, de Arnold Toynbee. Encontrar-se-á, nêste ensaio, um confronto de Max Weber com Toynbee.

${ }^{8}$ Recentemente se opera um movimento no sentido de distinguir o genuíno marxismo e sua importância científica da sua deformação política. Os epígonos do marxismo, a maioria dêles homens práticos e intelectuais marginais, associaram ao marxismo um necessarismo que, nas obras de Marx, 
é inexistente. J. L. Gray, um dos mais autorizados conhecedores inglêses de Karl Marx, na opinião de Howard Becker, escreve: "Foi a social-democracia alemã e não Karl Marx quem apadrinhou a noção de 'determinismo econômico' como lei sociológica completa. A doutrina de Kautsky - equivalente alemão do metodismo inglês - assegurou às massas exploradas que o milênio social havia de produzir-se sem necessidade de algum esforço feito por elas, simplesmente pela marcha irresistível dos acontecimentos econômicos. As opiniões de Marx... não postulavam êste necessarismo. Salvoulhe dêste defeito político a concepção da dialética e a teoria da luta de classe. Marx. .. acreditava no poder da vontade humana de forçar o ritmo da mudança social, de produzir uma revolução em um lugar de preferência a outro, em um momento de preferência a outro. A dialética não é uma filosofia determinista. É uma exposição do módulo geral pelo qual os homens mudam o mundo (Vide "Historia del Pensamiento Social”, pg. 626, vol. I. Fondo de Cultura Económica).

A êste respeito, consulte-se, ainda, a tradução brasileira de Crítica da Economia Política, de Karl Marx (Editora Flama), realizada por Florestan Fernandes, que a enriqueceu com um lúcido prefácio.

${ }^{9}$ Diz. Albert Salomon ("Max Weber's Political Ideas," op. cit): "The general tendencies of the historical process moreover revealed to him (Max Weber) the influence of "chanche" and its often incalculable significance. The fulfilment of the prophecy of Isaiah on the salvation of Jerusalen, historically an "accident", created the impregnable foundation for the position of Jahweh and the prophets in Israel. This observation of the "accidental" in the combination of series of historical causes always recurs in the works of Weber. This insight into the deep irrationality of history and economic life left him speechless and prevented him from offering a rationalistic or intelectualistic interpretation of the historical process. If he had been a rationalist in the manner of the humanism of Voltaire, politics and history would have seem to bim nothing but a must ridiculous play of human stupidity and baseness. But Weber never drew such consequences from his view of history".

${ }^{10}$ Op. cit. p. 4

${ }^{11}$ Cf. Max Weber, The Protestant Ethic and the Spirit of Capitalism, p. 26. Trad. de Talcott Parsons, London, 1930. Karl Mannheim faz um emprêgo mais claro dêstes termos, em seu livro, Liberdade e Planificação.

${ }^{12}$ Max Weber é autor de um estudo sobre música.

${ }^{13}$ Ec. y Soc. p. 40.

${ }^{14}$ De Max Weber: "A burocracia em seu pleno desenvolvimento se acha, também, em sentido específico, sob o princípio, sine ira ac studio. Sua peculiaridade específica, tão bem-aventurada para o capitalismo, a desenvolve num grau tanto maior quanto mais se "desumaniza", quanto mais completamente alcança as peculiaridades específicas que lhe são atribuídas como virtudes: a eliminação do amor, do ódio e de todos os elementos sensíveis puramente pessoais, de todos os elementos irracionais que se subtraem ao cálculo. Em vez do chefe das organizações antigas, movido pela simpatia pessoal, o favor, a graça e a recompensa, a civilização moderna exige justamente para o aparato externo que a protege um "especialista" rigorosamente objetivo e tanto menos interessado nas coisas propriamente humanas quanto mais seja complicada a civilização.” (Ecy Soc. Vol., IV, pp. 104-5).

15 “'Os estamentos (em alemão) stande: são os estratos sociais cuja posição está definida pela lei e pelo costume. Encontram-se, com variações, quase em todo ponto da Europa continental do velho regime e também no mundo antigo. As categorias são, em todas as partes, quase as mesmas. Na capa superior se encontram os nobres-governantes e defensores do Estado, - e os sacerdotes em seguida vêm os mercadores, os artesãos e os camponeses, cada um deles com deveres e funções mais ou menos claramente definidas, e finalmente tôda a variedade dos servos. As classes altas retêm 
numerosos privilégios - como a jurisdição privada - e imunidades, como a isenção de tributos. O nascimento decide da categoria e da posição. Os indivíduos ascendem de categoria ocasionalmente, mediante enobrecimento, por exemplo, e a Igreja recruta também seus membros, às vêzes, dos estratos inferiores. Mas em conjunto, cada estrato se recruta entre seus próprios membros e a ascensão depende da boa vontade das categorias superiores. Na Europa, o sistema estamental surgiu gradualmente, em regra geral, do feudalismo e conservou suas ordens até fins do século XVIII, especialmente a subordinação hierárquica e a dependência. As castas diferem dos estamentos por seu caráter religioso, sua maior rigidez e, talvez, também pelo fato de que nas primeiras, as diferenças de propriedade são relativamente pouco importantes. São, em essência, grupos profissionais e funcionais, intimamente afetados por diferenças de ritual ou cerimonial, constituindo um exemplo notável de influência dos fatôres irracionais sôbre a estimação social das ocupações e modos de vida. As modernas classes sociais diferem, em primeiro lugar, dos estamentos, pelo fato de não se basearem em diferenças de status legal. Em teoria existe igualdade ante a lei. Teoricamente, todas as ocupações e funções sociais são acessíveis a todos os homens e não existem restrições legais com respeito à aquisição da propriedade. Além disto, as classes sociais não têm a rigidez, nem das castas, nem dos estamentos. É possível uma quantidade considerável de movimentos de subida e descida e existem tantos estádios intermediários entre as classes que seus limites precisos são difíceis de determinar (Manual de Sociologia, Morris Ginsberg, Editorial Losada, 1942, pp. 147:8-9).

${ }^{16}$ Emilio Willems, "Burocracia e Patrimonialismo". in Administração Pública, n. 3, setembro, 945. S. Paulo.

${ }^{17}$ Esste estudo esboçado pelo próprio Weber tem sido possivelmente tentado em trabalhos dos quais temos referências, tais como R. Michels, "Sociologia del Partito Politico Moderno" e "Sociological Character of Political Parties" in American Political Science Review, nov. 1927.

${ }^{18}$ Vide Talcott Parsons, (The Review of Politics, números de janeiro e abril de 1942).

${ }^{19}$ Sôbre sociedade secular e sociedade sagrada, Barnes e Backer, História del Pensamiento Social, Cap. I. (Fondo de Cultura Económica).

${ }^{20}$ Um tipo sociológico de psicanàlise é o de Erich Fromm, cuja principal formulação teórica é, segundo Arnold W. Green, uma extensão psicológica da anàlise da ética protestante de Max Weber. Consulte Erich Fromm, Escape from Freedom, New York, 1941 e, ainda, Karen Horney, The Neurotic Personality of our Time, New York, 1937 e ElNuevo Psicanalisis, Fondo de Cultura Económica, México.

${ }^{21}$ Tawney, vide seu estudo, inserido na tradução inglesa de Talcott Parsons. "The Protestant Ethic and the Spirit of Capitalism". Vide, ainda, a obra de Tawney, "Religion and the Rise of Capitalism", Penguin Books, 1942.

${ }^{22}$ Max Weber. "The protestant...”p. 1 (c).

${ }^{23}$ O célebre quadro de Grantwood, O Gótico Americano, é uma eloquente ilustração pictórica dêste ascetismo intramundano.

${ }^{24}$ De Karl Marx, “Contribuição à Criíica da Economia Política” (Tradução de Florestan Fernandes, Ed. Flama): "O entesourador desdenha os gozos terrestres, temporais e transitórios, para correr atràs do tesouro eterno, que não pode ser corroído nem pelas formigas, nem pela ferrugem, e que é, ao mesmo tempo e completamente, celeste e terrestre” (pág. 139). - "Além disso, o entesourador, por pouco que seu ascestismo se reforce com uma enérgica aplicação ao trabalho, deve ser eminentemente praticante de sua religião e ainda mais puritano" (pág. 140). 
${ }^{25}$ Nem foi por outro motivo que o autor dêste trabalho no número anterior desta revista (“Administração e Política à Luz da Sociologia”) apresentou um programa de estudos sociológicos para técnicos de administração.

Alberto Guerreiro Ramos

Sociólogo e professor, nasceu na Bahia em 1915 e morreu em Los Angeles (Califórnia) em 1982. Em 1943, ingressou no DASP como técnico de administração, sendo marcante as suas contribuições à Revista do Servico Público entre 1946 e 1949. Uniu-se a Hélio Jaguaribe, Álvaro Vieira Pinto, Cândido Mendes, Nelson Werneck Sodré e Roland Corbisier para formar, em 1955, o Instituto Superior de Estudos Brasileiros (ISEB), entidade vinculada ao MEC para debater e produzir a ideologia desenvolvimentista no País. Desligou-se do instituto em 1958. Entre suas obras destacam-se A redução sociológica (1958), O problema nacional do Brasil (1960) e Mito e verdade da revolução brasileira (1963). 